\title{
The Characteristics and Main Controlling Factors for the Formation of Micropores in Shale from the Niutitang Formation, Wenshuicun Section, Southwest China
}

\author{
Danlong Li, Meiyan Fu *D, Yun Huang, Dong Wu and Rui Xue \\ College of Energy, Chengdu University of Technology, Chengdu 610059, China; \\ lidanlong99@stu.cdut.edu.cn (D.L.); huangyun@stu.cdut.edu.cn (Y.H.); wudong19@cdut.edu.cn (D.W.); \\ xuerui0926@stu.cdut.edu.cn (R.X.) \\ * Correspondence: fumeiyan08@cdut.cn
}

check for updates

Citation: Li, D.; Fu, M.; Huang, Y.; Wu, D.; Xue, R. The Characteristics and Main Controlling Factors for the Formation of Micropores in Shale from the Niutitang Formation, Wenshuicun Section, Southwest China. Energies 2021, 14, 7858. https://doi.org/10.3390/en14237858

Academic Editors: Mofazzal Hossain and Reza Rezaee

Received: 26 August 2021

Accepted: 18 November 2021

Published: 23 November 2021

Publisher's Note: MDPI stays neutral with regard to jurisdictional claims in published maps and institutional affiliations.

Copyright: (c) 2021 by the authors. Licensee MDPI, Basel, Switzerland. This article is an open access article distributed under the terms and conditions of the Creative Commons Attribution (CC BY) license (https:// creativecommons.org/licenses/by/ $4.0 /)$.

\begin{abstract}
The characteristics of shale micro-pore development and its main influencing factors have important theoretical guiding significance for shale gas exploration and resource evaluation. In order to clarify the micro-pore development characteristics of lower Cambrian shale and the main controlling factors of micro-pore development, we used the lower Cambrian Niutitang formation shale, in the Wenshuicun section of the Guizhou Province in southwest China. The micro-pore development characteristics of the shale in the region were studied by argon ion profile field emission scanning electron microscopy and a low-temperature liquid nitrogen adsorption and desorption experimental system. The relationship between micro-pore and kerogen maceral composition, total organic carbon (TOC) content and different mineral content was analyzed in combination with mineral and geochemical characteristics. Inorganic pores (clay mineral pores, dissolution pores and pyrite intergranular pores) and micro-fractures (clay mineral shrinkage crack, tectonic fractures and overpressure fractures) were the main type of pore developed in the shale of the Niutitang formation in the Wenshuicun section, and no organic pores had developed. The pore size of shale is usually $2-50 \mathrm{~nm}$, accounting for $58.33 \%$ of shale pores, e.g. mesopores. Clay mineral content has an obvious positive correlation with macropore volume and average pore diameter, and an obvious negative correlation with micropore volume. In addition, the content of feldspar in brittle minerals has a strong negative correlation with macropore volume and average pore diameter, and a strong positive correlation with micropore volume and BET-specific surface area. TOC content and the content of different kerogen macerals have no obvious correlation with the development of shale micropores in this region. It is concluded that inorganic mineral composition is the main controlling factor of micro-pore development within lower Cambrian shale, and organic matter abundance and maceral content have little influence on the micro-pore development. This study provides a case study for the characteristics of micropores in lower Cambrian shale in China.
\end{abstract}

Keywords: Wenshuicun, Guizhou Province; the lower Cambrian Niutitang formation; shale microscopic pore; characteristics; controlling factors

\section{Introduction}

With the success of the shale gas revolution in the United States, China has also made rapid advancements and great breakthroughs in shale gas exploration and development, becoming the first country to realize commercial-scale development after the U.S. [1,2]. "sweet areas" have been discovered and commercialized in Weiyuan and Changning of the Sichuan Basin, and shale gas has been discovered in Triassic formations within the Ordos Basin and Cengong of Southeastern Guizhou province [3-6].

Micro-nano pores, especially organic pores, are important reservoir spaces for shale gas. In the process of the pyrolysis of residual oil and bitumen into gas, abundant organic matter pores are produced [7]. The pore development of shale is an important consideration 
when evaluating the gas-bearing property of shale reservoirs. Previous studies have shown that shale reservoirs mainly consist of micron-nano scale pores [8]. Among these, organic pores are an important reservoir space for oil and gas in marine shale with high-over maturity [9]. Therefore, it is very important to study and characterize the development of microscopic pores in shale. More and more researchers are paying attention to the development of these pores and their controlled factors, and have discovered many important results. Generally speaking, shale pore development is mainly affected by thermal maturity, organic matter abundance, kerogen maceral and mineral content, as well as other factors [10-15]. The relationship between thermal evolution degree and pore structure characteristics has obvious stage characteristics, which means that the porosity increases when the Ro(vitrinite reflectance) of the Niutitang shale reservoir is between $0.6 \%$ and $3 \%$, and the pore structure is well developed; however, when Ro is more than $3.5 \%$, it is adverse to pore development, and can even destroy the original pore structure and eventually lead to the disappearance of the pores $[10,16]$. Some scholars have also proposed that organic pores and micro-cracks develop in large quantities in the high-mature to over-mature stage $[11,12]$. In the polar development stage of organic pores, there is a positive correlation between TOC and pore volume of different pore sizes and total pore volume $[13,14]$. Cao et al. (2018) [15] theorized that vitrinite in kerogen maceral contributes less to micropore development, and only develops certain shrinkage cracks in its interior and edge; this is because the sapropelic formation is the favorable composition of organic pore development and the main contributor of micro-pores. Compared with other macerals, algae I and solid bitumen have larger and more abundant organic pores [17]. The high content of brittle minerals is beneficial to the development of medium and large pores [10]. Based on the previous studies mostly focused on the overall pore characteristics of lower Cambrian shale, the origin of micro-pores in the Cambrian shale was complicate.

The Niutitang formation is the most potential layer among marine shales in the Sichuan Basin, China. However, at present, the understanding of the pore system of the Niutitang formation is not clear, especially regarding the development degree of organic pores. In this paper, the characteristics and controlling factors of the pore system of overmature lower Cambrian shale dominated by sapropelic formation are discussed. Through the measurement of shale samples from different horizons on the profile, pore types of shale were observed and classified by argon ion profile field emission scanning electron microscope, and the following two problems were analyzed in combination with mineral composition and geochemical characteristics such as kerogen macerals and total organic carbon content: (1) the influence of organic matter type and maturity on organic matter pore development in the lower Cambrian shale; (2) influencing factors of shale pore development. Through this study, we hope to have achieved a preliminary understanding of the pore system development in the lower Cambrian Niutitang formation shale in Guizhou province, and, thus, provide theoretical reference for the exploration and resource evaluation of marine shale gas in China. At the same time, through the study of pore system, the occurrence state of shale gas could be clearly defined, which could provide the basis for the next well location deployment and fracturing method so as to maximize the production during the development process.

\section{Geological Setting}

During the Paleozoic period, due to large sea invasion, four sets of black shale formed in the middle of the Yangtze region, including lower Cambrian, upper Ordovician-lower Silurian, lower Permian and upper Permian shale [18]. Among them, the lower Cambrian shale is widely distributed in the Middle-Upper Yangtze area. Li et al. (2018) [19] pointed out that since the Sinian period, the Middle-Upper Yangtze region can be divided into three tectonic sequences: Sinian to Silurian, Devonian to Triassic and Jurassic to Neogene, each of which can form a complete Wilson cycle. The Wenshuicun region of Baihua Lake Town in the Guanshan Lake area, Guizhou province, is located in the southeast of the central Guizhou uplift area, where the lower Cambrian Niutitang formation developed, 
and its sedimentary environment is shallow sea shelf facies [20]. The underlying layer of the Niutitang formation is the Sinian Dengying formation, which presents an unconformable contact relationship [21]. The lower Cambrian organic rich black shale in this section was formed in the early Cambrian period due to the breakup of the southern Pangea caused by extensional activities and the large-scale transgression of the ocean floor [22]. There are many types of hydrocarbon generation organism. Existing research results show that high-quality hydrocarbon generation organisms in marine shale mainly include three categories: planktonic algae; benthic organisms; and fungi. Among them, planktonic algae is equivalent in hydrocarbon generation potential to type I kerogen, and benthic algae is equivalent to type II kerogen [23-25]. This set of shale is widely distributed, of high maturity (belonging to the over-mature stage), with high total organic carbon content, great hydrocarbon generation potential and great shale gas exploration potential $[14,23,26]$.

\section{Materials and Methods}

\subsection{Materials}

Inside the Sichuan Basin, the lower Cambrian layer is basically not exposed, and the exposure at the edge of the basin is also very poor. As a representative layer of the lower Cambrian, the Niutitang formation has complete exposure in Wenshuicun section, whose organic-rich shales are well developed, and it represents deep-water shelf facies deposits on the passive continental margin. It is a very representative exposure layer of marine shale in the Lower Cambrian, China. According to the change of region lithology, we subdivided it. In the subdivision of lithology we found many argillaceous siltstones, so we selected the most representative shale samples in 10 exposed sites as experimental materials for analysis and research, from 26 samples. The top of the collected samples was black laminar shale, followed by massive silty shale, black laminar shale, middle siliceous shale, middle siliceous silty shale, and black carbonaceous shale at the bottom, so as to reflect the characteristics of shale in the whole profile (Figure 1).

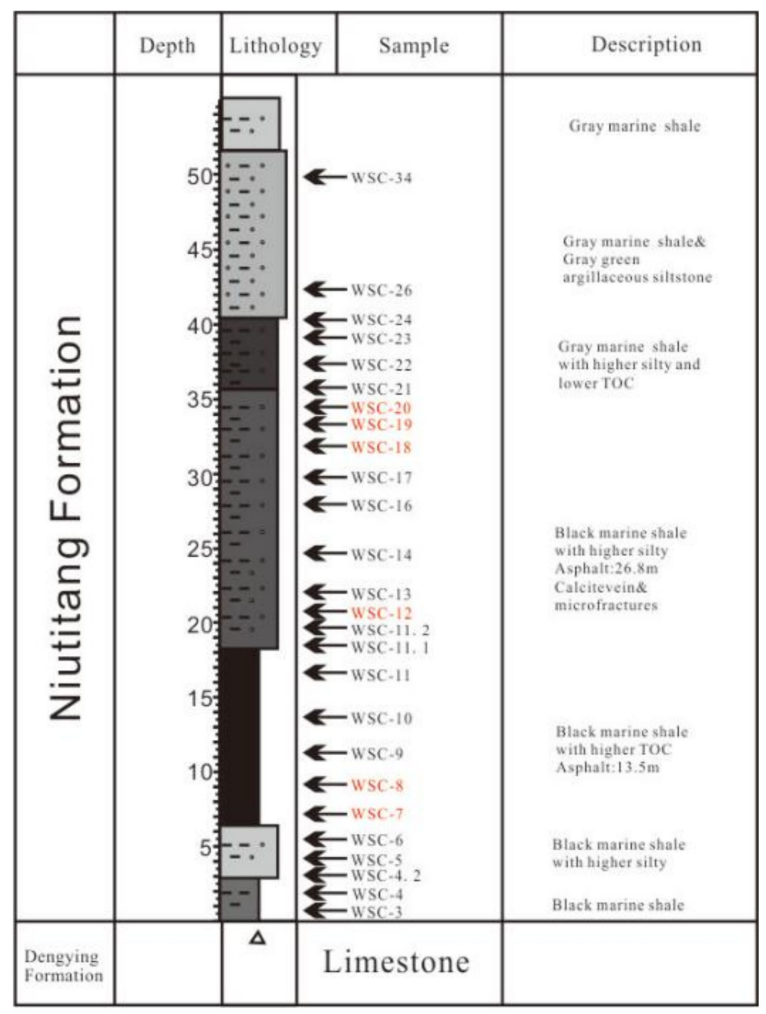

Figure 1. The column chart of sampled lithology in Wenshuicun section, Guizhou province. (Notice: the sample marked red is the sample used in this experiment.) 


\subsection{Methods}

\subsubsection{Pore Types}

For the observation and analysis of the pore system development of shale samples in the outcrop profile of Wenshuicun section in Guizhou, we used the Quanta 250 FEG field emission environmental scanning electron microscope and Inca x-max20 energy spectrum analyzer, as this microscope has an ultra-high resolution. Using secondary electron imaging, we could obtain the ultra-fine morphology and structure information of the sample surface in a strong three-dimensional sense, so as to observe the pore development of the samples properly. At the same time, the high-performance X-ray energy spectrometer could qualitatively analyze the elements contained in the sample, which helped us to identify the pore type. The experimental process was to grind the sample into $1 \mathrm{~cm} \times 1 \mathrm{~cm} \times 0.3 \mathrm{~cm}$. Then, the sample was polished for $6 \mathrm{~h}$ on the polishing machine and sprayed with gold. Finally, it was observed by electron microscopy and analyzed qualitatively by energy dispersive spectrometry.

\subsubsection{Pore Size}

In this paper, a mature and widely used experimental method for determining pore size distribution-low-temperature liquid nitrogen adsorption-desorption [27-29] —was used to characterize the shale samples. The experiment used the isothermal adsorption characteristic curve of nitrogen to determine the pore volume and pore size distribution of shale samples through theoretical analysis. Since the samples came from the outcrop profile, we extracted them at a depth of $10 \mathrm{~cm}$ from the ground surface, and removed the weathered layer on the sample surface before the experiment to ensure the reliability of the experimental data.

\subsubsection{Mineral Composition}

According to the SY / T5163-2018 "X-ray Diffraction Analysis Methods for Clay Minerals and Common Non-Clay Minerals in Sedimentary Rocks", the shale samples were analyzed using Ultima IV, X-ray Diffraction. Because different crystal structures diffract different intensities, different composition can be distinguished. In this way, we could observe and analyze the mineral composition and clay mineral composition of the samples. The experimental process was carried out in the following steps: we washed the oil-containing sample, dried the wet sample below $60^{\circ} \mathrm{C}$ and cooled it to room temperature; then the sample was crushed and ground with a crushing prototype or copper mortar until the size of all particles was less than $40 \mu \mathrm{m}$; finally, the back pressure method was used to make the measuring sheet, which, once polished and leveled, was sent to X-ray diffraction for detection.

\subsubsection{Thermal Maturity}

Firstly, the sample particles were consolidated and formed with inlaid resin, polished until there were no stains, needle scratches or cloth patterns, and the boundary between components was clear. Then, the asphalt reflectance of the sample was measured by a reflectance tester. It is generally believed that vitrinite reflectance is the most reliable maturity index [30,31]. Therefore, we used the following formulas to convert asphalt reflectance to vitrinite reflectance to characterize shale organic matter maturity: (Equation (1) [32]; Equation (2) [33])

$$
\begin{gathered}
\mathrm{R}_{\mathrm{o} 1}=0.3364+0.6569 \mathrm{R}_{\mathrm{bo}} \\
\mathrm{R}_{\mathrm{o} 2}=0.4+0.618 \mathrm{R}_{\mathrm{bo}}
\end{gathered}
$$

\subsubsection{Abundance of Organic Matter}

Organic matter abundance in shale is usually evaluated by measuring the total organic carbon content (TOC) of shale and the mass fraction of chloroform bitumen " $\mathrm{A}$ " [34]. For this set of shale, we evaluated the abundance of organic matter by measuring TOC. 
According to GB/T 19145-2003 "Determination of total Organic carbon in Sedimentary Rocks" standard, the sample was crushed to a size of $0.15 \mathrm{~mm}$, before $4.5 \sim 4.75 \%$ hydrochloric acid solution was slowly added. The sample was then dissolved in a water bath for $2 \mathrm{~h}$, and, afterwards, placed in a crucible on the extraction filter and cleaned with distilled water until it was neutral. Then, the crucible containing the samples was dried in an oven $\left(80^{\circ} \mathrm{C}\right)$. Finally, the LECO CS230, sulfur and carbon analyzer, and AE-160, analytical balance, were used to determine and analyze the shale samples.

\subsubsection{Types of Organic Matter}

The kerogen macerals were measured based on SY/T 515-2014 "Transmittance LightFluorescence Kerogen Maceral Identification and Type Classification Method". Polyvinyl alcohol and distilled water were mixed and prepared into polyvinyl alcohol solution at a ratio of 1:9-1:11. The polyvinyl alcohol solution was fully mixed with the sample on the cover glass, and then coated with a non-fluorescent binder after natural drying, and then flipped onto the carry sheet glass. Finally, LEICA DM4500P, a rock kerogen microscopy analyzer, was used to analyze the samples.

\section{Results}

\subsection{Pore Types}

According to the experimental results, it was found that inorganic pores are commonly developed in the black shale samples of the Wenshuicun region, including clay mineral shrinkage fractures and dissolution pores, and pyrite intercrystalline pores. The pore size was nanometer-level; some cracks were only about $20 \mathrm{~nm}$, while large dissolution pores and cracks could reach several microns, but most of them were between hundreds of nanometers, and the cracks developed into complex fracture networks. Pyrite was more developed, with the development of berrylike pyrite and single crystal pyrite, mostly of triangular, square and irregular shapes. Microscopically, large amounts of organic matter could be observed to be filled with pyrite or developed in association with clay minerals, but organic pores were hardly developed (Figure 2).

\subsection{Characteristics of Pore Size, Pore Volume and Specific Surface Area}

Shale pores are divided into micro-pores $(<2 \mathrm{~nm})$, mesoporous $(2-50 \mathrm{~nm})$ and macro-pores $(>50 \mathrm{~nm})$ according to the commonly accepted characterization standards of shale gas reservoir pores. The results show that the nano-scale pores of the shale in this section were well developed. $89.58 \%$ of the pores were smaller than $100 \mathrm{~nm}$, and the micro-pores accounted for $20.72 \%$. The volume range was $(0.68-4.08) \times 10^{-3} \mathrm{~cm}^{3} / \mathrm{g}$, with an average of $2.313 \times 10^{-3} \mathrm{~cm}^{3} / \mathrm{g}$. The mesopores accounted for $58.33 \%$. The volume range was $(4.2-8.58) \times 10^{-3} \mathrm{~cm}^{3} / \mathrm{g}$, with an average of $6.51 \times 10^{-3} \mathrm{~cm}^{3} / \mathrm{g}$. Macro-pores made up $20.95 \%$. The volume range was $(1.43-5.27) \times 10^{-3} \mathrm{~cm}^{3} / \mathrm{g}$, with an average of $2.338 \times 10^{-3} \mathrm{~cm}^{3} / \mathrm{g}$ (Figure 3), indicating that the pores in this section were mainly mesoporous. The BET-specific surface area of this section ranged from $6.76-17.18 \mathrm{~m}^{2} / \mathrm{g}$, with an average of $12.80 \mathrm{~m}^{2} / \mathrm{g}$.

\subsection{Mineral Composition Characteristics}

The mineral composition and clay mineral composition of shale samples were observed and analyzed by X-ray diffraction. According to the results of the experiment, the mineral components of Wenshuicun's lower Cambrian black cattle hoof pond group shale are complex, containing detrital minerals, such as quartz, potash feldspar, plagioclase and so on. The carbonate minerals include calcite, dolomite and siderite, etc. Pyrite and a small amount of gypsum, anhydrite and halite and other amorphous minerals could be seen in some samples. At the same time, the clay minerals contained illite, kaolinite and an illite-smectite mixed layer, but no smectite, indicating that the smectite had been completely transformed into illite, and the proportion of the smectite layer in the I/S mixed layer is zero, meaning that it belonged to the late diagenetic stage. In WSC-20Z, a $1.59 \%$ chlorite-kaolinite mixed layer was found, but not in other samples. The shale was 
dominated by clay minerals, the content of which ranged from $25.82 \%$ to $60.77 \%$, with an average of $43.68 \%$. Quartz was second, with an average of $38.57 \%$, ranging from $33.81 \%$ to $42.79 \%$ (Table 1 and Figure 4). Illite was the main clay mineral, the content of which ranged from $39.02 \%$ to $82.17 \%$, with an average of $67.35 \%$. The second was the illite-smectite mixed layer, with an average content of $23.69 \%$.
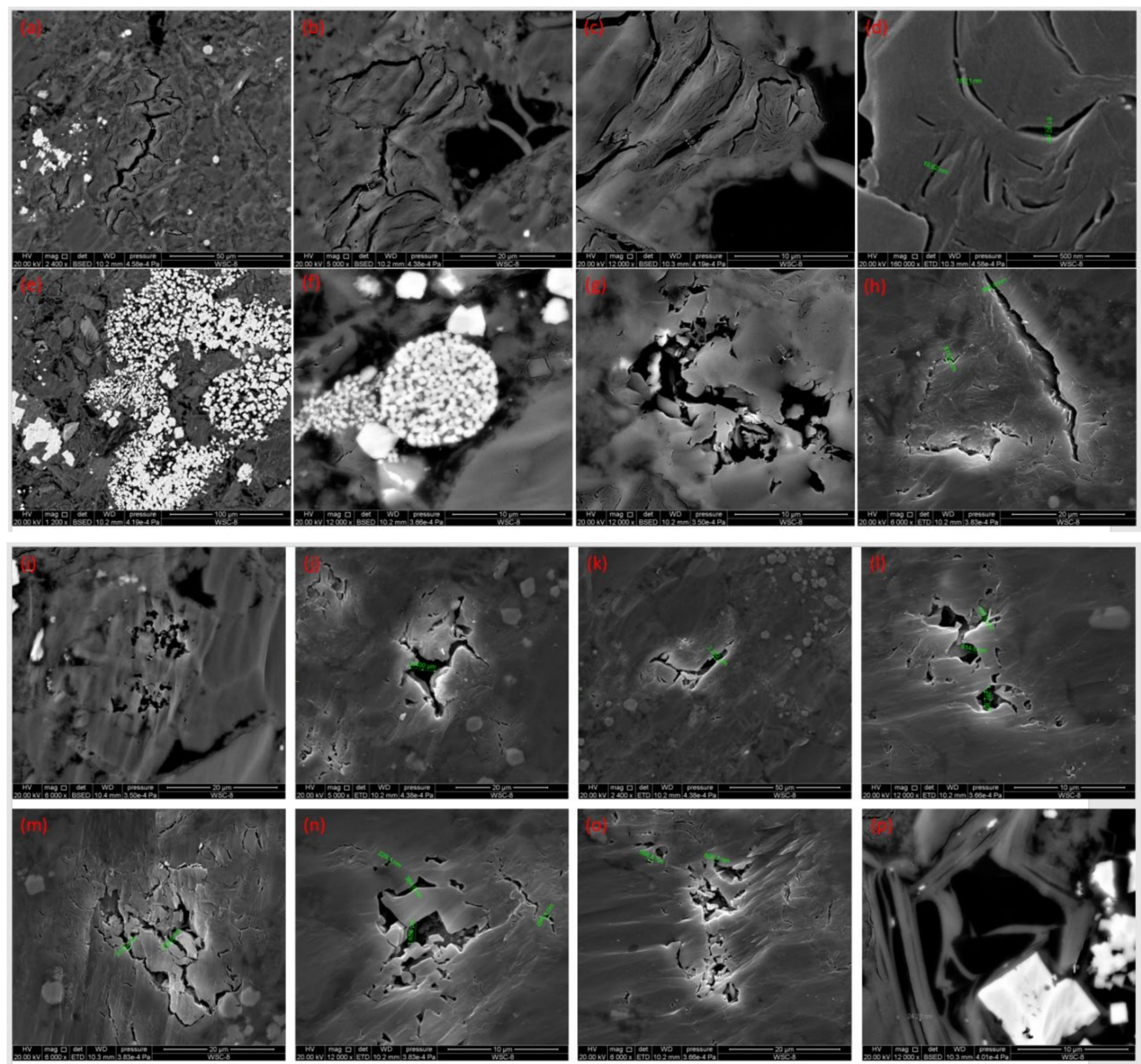

Figure 2. Development characteristics of nanometer pores in black shale of the Niutitang formation in Wenshuicun, Guizhou. (a-d)—clay mineral shrinkage crack; (e)—filling with organic matter in pyrite; (f) — framboidal pyrite intergranular pore; $(\mathbf{g}, \mathbf{i}-\mathbf{o})$ - clay mineral dissolution pore; $(\mathbf{h})$-tectonic fractures; $(\mathbf{p})$-overpressure fracture. 

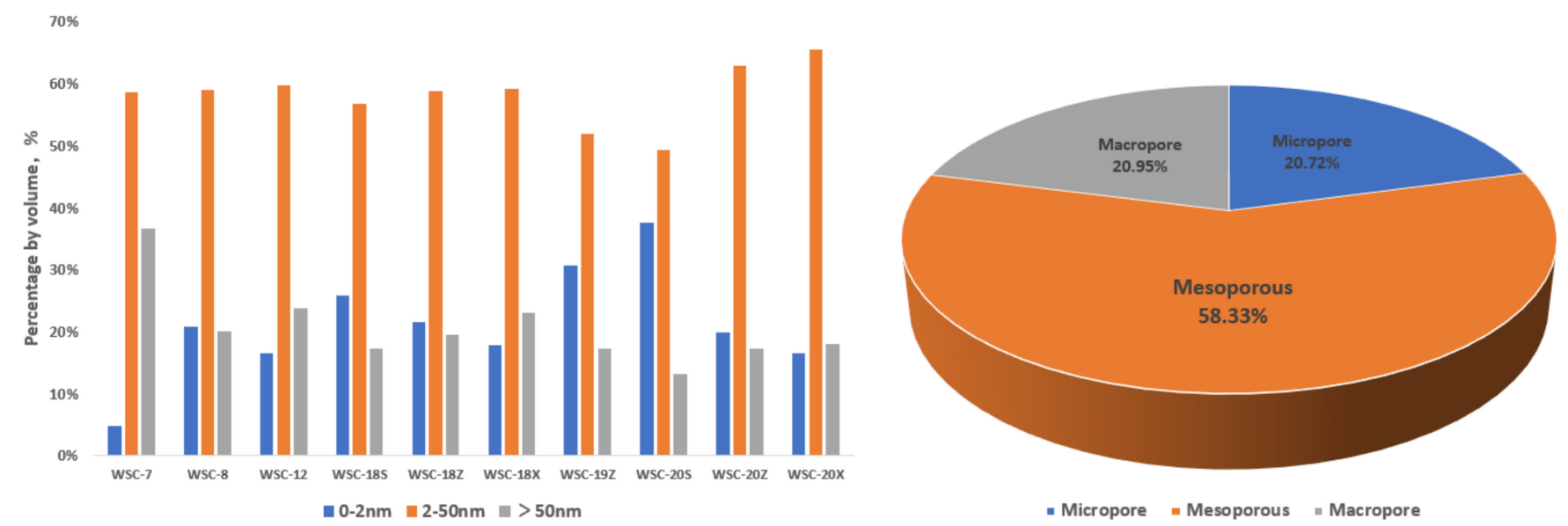

Figure 3. Range of shale pore sizes in Wenshuicun section, Guizhou province.

Table 1. The X-ray diffraction experiment results of lower Cambrian black shale from the Niutitang formation in Wenshuicun, Guizhou.

\begin{tabular}{ccccccccccc}
\hline \multirow{2}{*}{ No. } & \multirow{2}{*}{ Sample ID } & \multicolumn{4}{c}{ Mineralogical Composition (\%) } & \multicolumn{3}{c}{ Clay Composition (\%) } \\
\cline { 3 - 10 } & & Quartz & Feldspar & Carbonate & Pyrite & Clay & I & K & I/S & C/S \\
\hline 1 & WSC-7 & 35.30 & 2.32 & 1.15 & 0.46 & 60.77 & 39.02 & 19.1 & 41.88 & - \\
2 & WSC-8 & 33.81 & 3.07 & 9.94 & 10.3 & 42.93 & 55.54 & 11.19 & 33.27 & - \\
3 & WSC-12 & 36.98 & 9.33 & 2.04 & 4.29 & 46.72 & 47.91 & 16.86 & 35.23 & - \\
4 & WSC-18X & 35.82 & 6.25 & 0.41 & 0.30 & 57.22 & 57.85 & 10.35 & 31.80 & - \\
5 & WSC-18Z & 41.35 & 13.82 & 0.82 & - & 43.87 & 82.17 & 3.96 & 13.87 & - \\
6 & WSC-18S & 41.18 & 12.9 & 1.61 & - & 44.31 & 79.74 & 5.12 & 15.14 & - \\
7 & WSC-19Z & 39.56 & 17.38 & 1.5 & 1.04 & 40.52 & 79.75 & 6.31 & 13.94 & - \\
8 & WSC-20X & 41.75 & 20.53 & 0.23 & - & 37.49 & 73.60 & 3.22 & 23.18 & - \\
9 & WSC-20Z & 42.79 & 17.7 & 1.62 & - & 37.19 & 80.15 & 3.24 & 15.02 & 1.59 \\
10 & WSC-20S & 37.20 & 21.01 & 10.7 & 5.00 & 25.82 & 77.80 & 8.59 & 13.61 \\
\hline
\end{tabular}

Note: I—illite; S—smectite; K—kaolinite; C—chlorite; I/S—illite-smectite mixed layer; C/S—chlorite-kaolinite mixed layer.

120

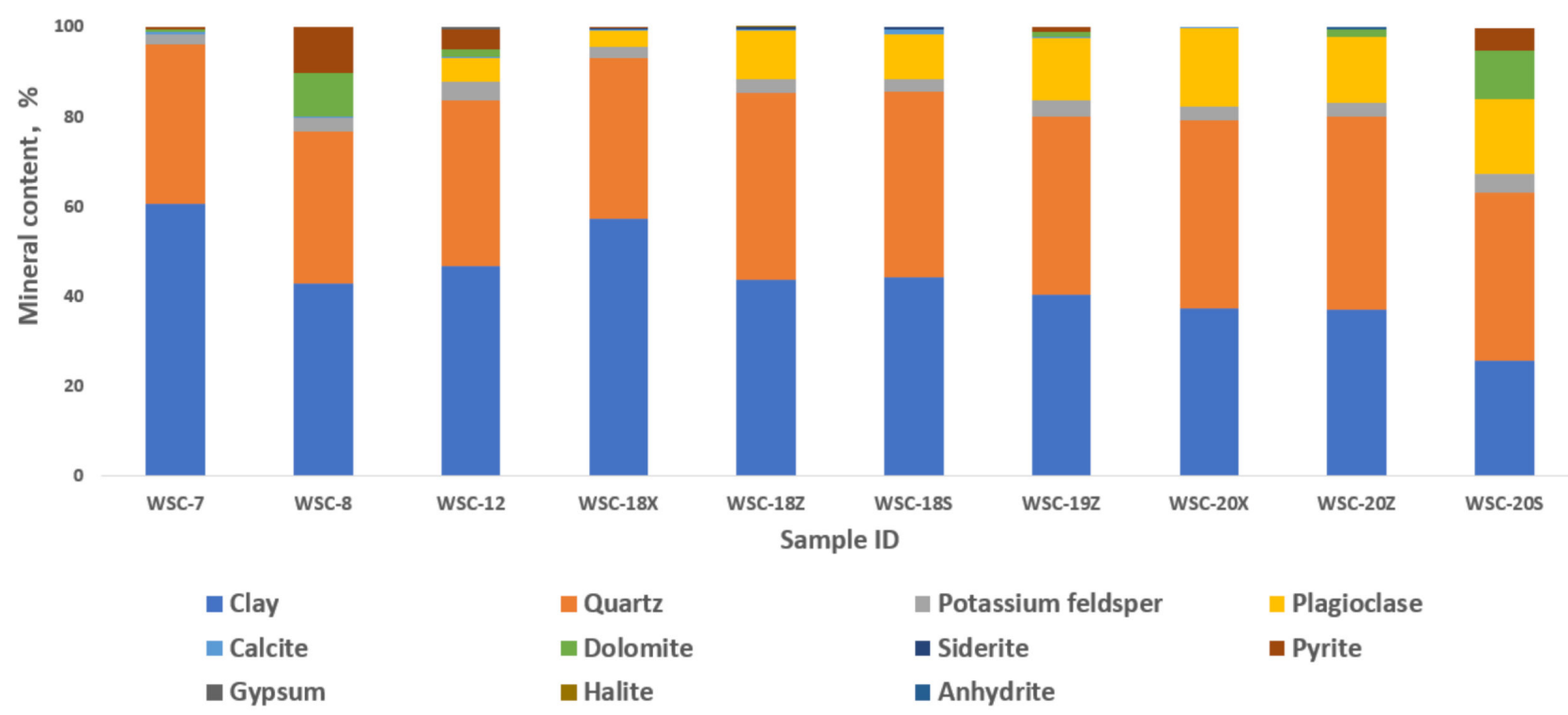

Figure 4. Mineral composition and content distribution of lower Cambrian shale from the Niutitang formation in Wenshuicun, Guizhou. 


\subsection{Thermal Maturity}

According to Section 3.2.4 Equation (1), the vitrinite reflectance of the lower Cambrian black shale in Wenshuicun was between $2.89 \%$ and $2.98 \%$, with an average value of $2.93 \%$. According to Section 3.2.4 Equation (2), the vitrinite reflectance ranged from $2.80 \%$ to $2.88 \%$, with an average value of $2.84 \%$ (Table 2). It was thus concluded that this set of shale belonged to the over-mature stage.

Table 2. Conversion results of vitrinite reflectance and bitumen reflectance of lower Cambrian black shale in Wenshuicun, Guizhou.

\begin{tabular}{cccc}
\hline Sample ID & $\mathbf{R}_{\mathbf{b o}}, \mathbf{\%}$ & $\mathbf{R}_{\mathbf{o 1}}, \mathbf{\%}$ & $\mathbf{R}_{\mathbf{o} 2}, \mathbf{\%}$ \\
\hline WSC-7 & 3.89 & 2.89 & 2.80 \\
WSC-12 & 3.98 & 2.95 & 2.86 \\
WSC-18X & 3.94 & 2.92 & 2.83 \\
WSC-19Z & 4.02 & 2.98 & 2.88 \\
WSC-20Z & 3.93 & 2.92 & 2.83 \\
Average & 3.95 & 2.93 & 2.84 \\
\hline
\end{tabular}

Note: $\mathrm{R}_{\mathrm{o} 1}=0.3364+0.6569 \mathrm{R}_{\mathrm{bo}} ; \mathrm{R}_{\mathrm{o} 2}=0.4+0.618 \mathrm{R}_{\mathrm{bo}}$.

\subsection{Abundance of Organic Matter}

The results show that the total organic carbon content of the lower Cambrian black shale in Wenshuicun was generally high, with the highest value being $5.22 \%$. The measured total organic carbon (TOC) content was between $0.98 \%$ and $5.22 \%$, with an average of $2.72 \%$ (Table 3 ). This means it has good hydrocarbon generation potential and is a good source rock.

Table 3. Test results of total organic carbon content of lower Cambrian black shale in Wenshuicun, Guizhou.

\begin{tabular}{cccccccccccc}
\hline Sample ID & WSC-7 & WSC-8 & WSC-12 & WSC-18X & WSC-18Z & WSC-18S & WSC-19Z & WSC-20X & WSC-20Z & WSC-20S & Average \\
\hline TOC $/ \%$ & 2.98 & 5.22 & 2.51 & 2.07 & 0.98 & 1.41 & 2.62 & 3.12 & 3.06 & 3.21 & 2.72 \\
\hline
\end{tabular}

\subsection{Types of Organic Matter}

According to the results of kerogen macerals, it was found that the black shale of the lower Cambrian Niutitang formation was mainly composed of sapropelinite, accounting for $92.60 \%$, followed by vitrinite, accounting for $6.12 \%$. The contents of exinite and inertinite were very small, accounting for only $0.66 \%$ and $0.62 \%$ (Figure 5 ). In sapropelinite, the sapropelic amorphous body was the main component, and no other submicroscopic components were found. The normal vitrinite was dominant in vitrinite, and a small amount of hydrogen-rich vitrinite was found in some samples. Only a few samples of cutinite and mycetome were found in some samples of chitin, and no other components were found. Inertinite contained only a small amount of fusinite (Table 4). The shale kerogen in this section belonged to type I kerogen by hydrogen-like index calculation.

Table 4. Kerogen maceral results of lower Cambrian Niutitang formation black shale in Wenshuicun, Guizhou.

\begin{tabular}{|c|c|c|c|c|c|c|c|c|}
\hline \multirow{2}{*}{ Sample ID } & \multirow{2}{*}{$\begin{array}{c}\text { Sapropelinite(\%) } \\
\text { Sapropelic } \\
\text { Amorphous Body }\end{array}$} & \multicolumn{2}{|c|}{ Exinite(\%) } & \multicolumn{2}{|c|}{ Vitrinite $(\%)$} & \multirow{2}{*}{$\begin{array}{c}\text { Inertinite(\%) } \\
\text { Fusinite }\end{array}$} & \multirow{2}{*}{$\begin{array}{l}\text { Hydrogen-Like } \\
\text { Index }\end{array}$} & \multirow{2}{*}{$\begin{array}{c}\text { Organic } \\
\text { Matter Type }\end{array}$} \\
\hline & & Cutinite & Mycetome & $\begin{array}{l}\text { Hydrogen-rich } \\
\text { Vitrinite }\end{array}$ & $\begin{array}{l}\text { Normal } \\
\text { Vitrinite }\end{array}$ & & & \\
\hline WSC-7 & 96.01 & - & 0.33 & - & 2.99 & 0.66 & 93.27 & I \\
\hline WSC-8 & 92.05 & 0.66 & - & - & 5.96 & 1.32 & 86.59 & I \\
\hline WSC-12 & 93.67 & 0.67 & - & - & 5.33 & 0.33 & 89.67 & I \\
\hline WSC-18X & 90.07 & 0.33 & - & - & 9.60 & - & 83.03 & I \\
\hline WSC-18Z & 88.37 & - & - & 0.66 & 10.30 & 0.66 & 80.05 & I \\
\hline WSC-18S & 89.04 & 0.66 & - & 0.33 & 9.30 & 0.66 & 81.76 & I \\
\hline WSC-19Z & 96.01 & 0.66 & 0.33 & 0.33 & 2.66 & - & 94.55 & I \\
\hline WSC-20X & 92.43 & - & - & - & 7.24 & 0.33 & 86.68 & I \\
\hline WSC-20Z & 95.03 & 0.33 & - & - & 4.30 & 0.33 & 91.64 & I \\
\hline WSC-20S & 95.71 & 1.32 & - & - & 2.31 & 0.66 & 93.98 & I \\
\hline
\end{tabular}




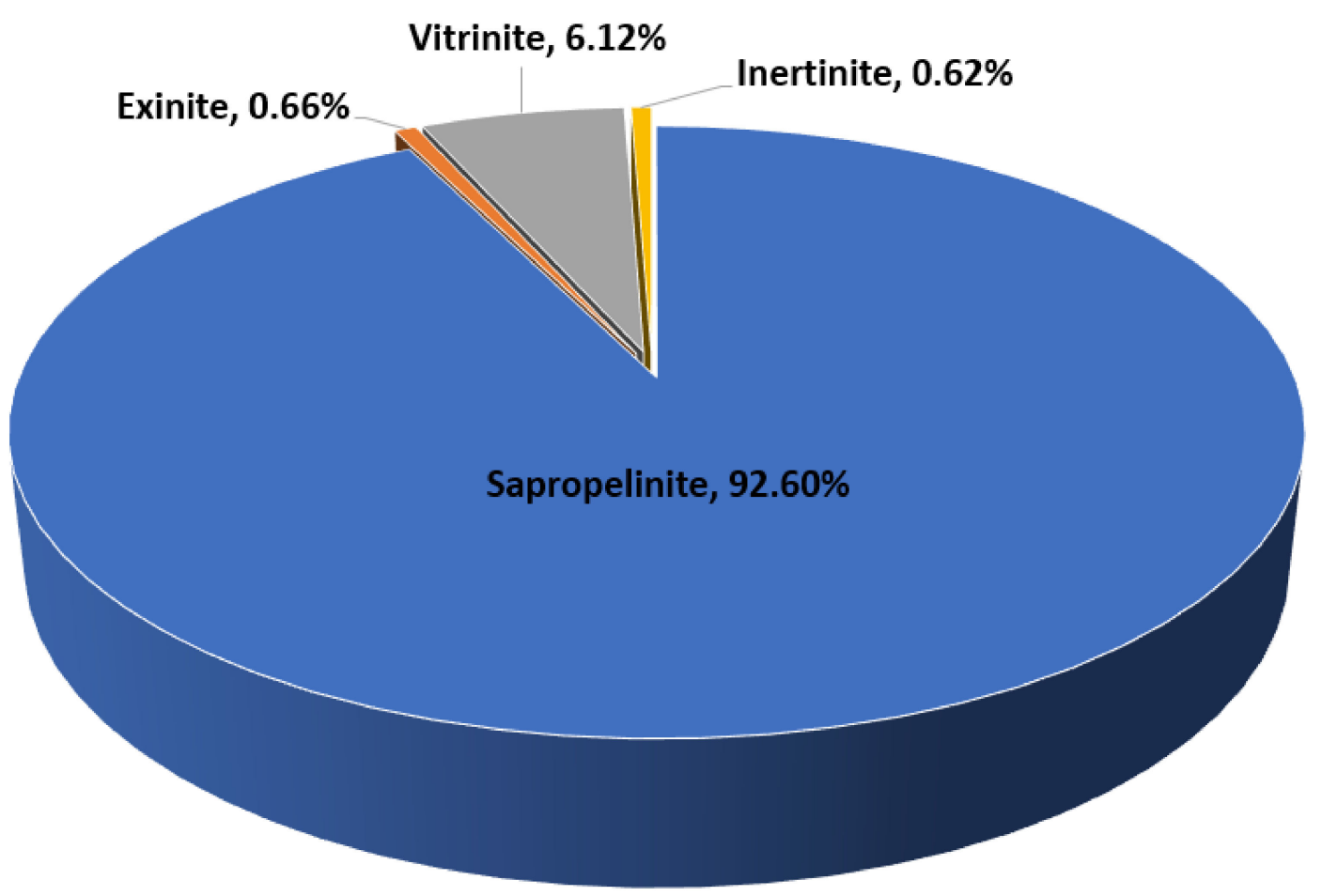

\section{Sapropelinite Exinite vitrinite $\square$ Inertinite}

Figure 5. Relative ratio of kerogen maceral of lower Cambrian Niutitang formation black shale in Wenshuicun section, Guizhou province.

\section{Discussion}

Pore development in shale reservoirs is complex and changeable, and pore formation is influenced by many factors, including not only external factors such as tectonics, sedimentary diagenesis and compaction, but also internal factors such as mineral composition, organic matter type and total organic carbon content, which often interact with and restrict each other [35]. Therefore, the factors influencing the development of shale microscopic pores are complex and variable. This paper mainly discusses the internal factors that affect the development of microscopic pores of shale in Wenshuicun.

\subsection{Effect of BET Specific Surface Area on Pore Size}

The correlation analysis between different pore sizes and BET-specific surface area was made using a scatter plot. It was found that the micro-pores contributed the most to specific surface area. Figure 6 shows that the specific surface area has a high positive correlation with the volume of micro-pores (the correlation coefficient is 0.9215), a good negative correlation with the average pore size (the correlation coefficient is 0.6661 ), and a poor or no correlation with other pore size ranges. It indicates that in shale reservoirs, the smaller the pore size of shale is, the greater the contribution to specific surface area will be, which is more conducive to the adsorption and accumulation of shale gas. Morevoer, the specific surface area will also increase with the increase of micropore volume. 

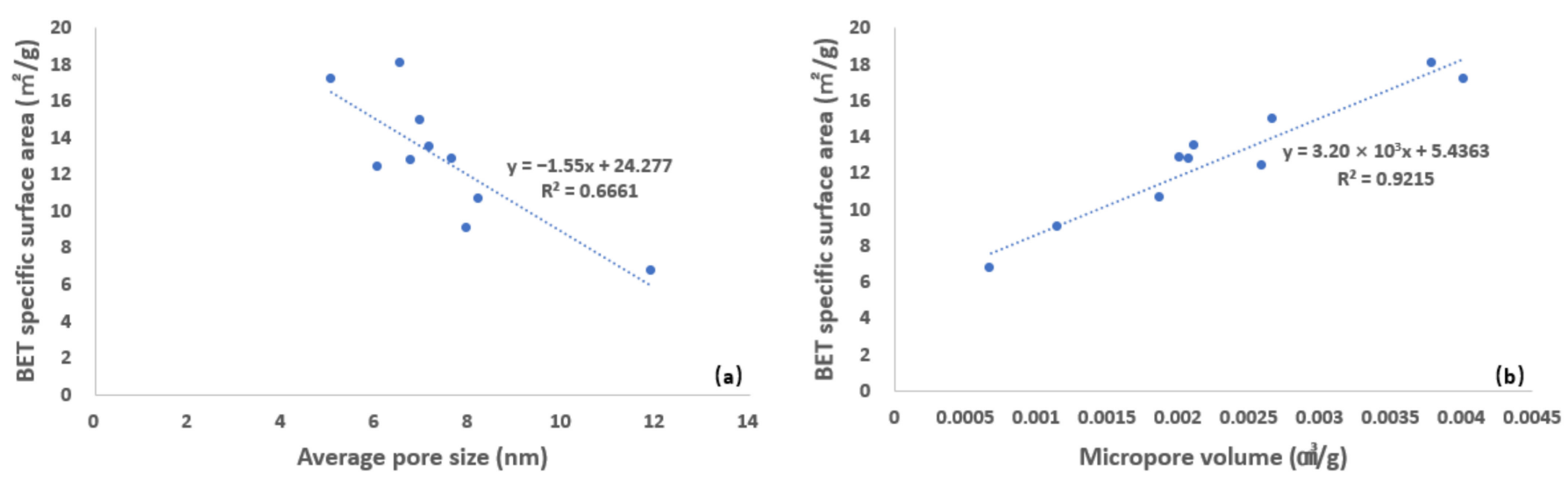

Figure 6. Relationship between BET-specific surface area and pores; (a) the cross plot of BET-specific surface area and the average pore size; (b) the cross plot of BET-specific surface area and the micropore volume.

\subsection{The Influence of Organic Matter Composition on Organic Pore Development in Lower Cambrian Shale}

5.2.1. The Influence of Organic Matter Abundance on Organic Pore Development

A large number of micro-nano pores are formed during hydrocarbon generation and the expulsion of organic matter. The specific surface area and pore volume of nano-pores in shale are significantly affected by total organic carbon [36-38]. He et al. (2019) [39] surmised that the pore development of different lithofacies shales is controlled by TOC and mineral components obeying different mechanisms. The pore structure of siliceous shales is mainly affected by TOC and biosiliceous content, and the pore structure of mixed-minerals shales is mainly affected by TOC and clay mineral content. Wang et al. (2017) [40] contended that TOC content took $6.5 \%$ as the cut-off point, and if it was lower than $6.5 \%$, TOC content was positively correlated with porosity and total pore volume; above $6.5 \%$, the shale is more likely to be compactified due to increased plasticity, so the positive correlation gradually becomes a negative correlation. Indeed, Zhang et al. (2019) [41] also found that TOC was the main controlling factor of micro-pore development in the lower Cambrian shale from the Niutitang formation with over maturity, which was basically unaffected by tectonic stress difference. By establishing the relationship between TOC and different types of microscopic pores, it was found that the total organic carbon content of Niutitang formation black shale in Wenshuicun has a weak or no correlation with the micropore volume, mesoporous volume, macropore volume, total pore volume and average pore size (Figure 7a-f). The above evidence shows that TOC content has little effect on microscopic pores in this section.

\subsubsection{The Influence of Organic Matter Types on Organic Pore Development}

The development of organic pores is influenced by maceral [42]. Cao et al. (2018) [15] found, in combination with the previous research results, that vitrinite and solid bitumen were not the main contributors to the development of organic pores in the high maturity stage, while sapropelinite was the most favorable component for the development of organic pores. Long et al. (2012) [35] also found that sapropelinite was favorable for pore development and was the most likely to form pores. However, they also concluded that vitinite had a strong hydrocarbon generation capacity and that abnormal pressure generated in the thermal evolution process would rupture organic matter and form pores. For example, micro-pores and mesopores are developed in the matrix vitrinite, and macro-pores are developed in the lumen of the fusinite of remaining plant tissues [43]. Jiang et al. (2021) [44] found that the maceral difference of organic matter plays an important role in controlling the pore development of continental shale reservoir, and high saprophytic content $(>60 \%)$ is the guarantor of superior reservoir capacity. Similarly, in this study, a scatter plot was used to establish the correlation between different macerals and microscopic pores. Our analysis shows that the sapropelinite in kerogen macerals was weakly correlated with 
mesoporous volume, total pore volume and BET-specific surface area, and the correlation coefficients were $R^{2}=0.1325, R^{2}=0.1023, R^{2}=0.1476$. The correlation is not obvious or non-existent with other types of pores (Figure 8); there is a weak correlation between vitrinite and mesoporous volume and total pore volume $\left(R^{2}=0.1623\right.$ and $\left.R^{2}=0.1024\right)$, but there is no obvious correlation or no correlation between vitrinite and other types of pore size (Figure 9). Due to the low content of exinite and inertinite, the reference value is not ideal, and analysis and evaluation were not completed.
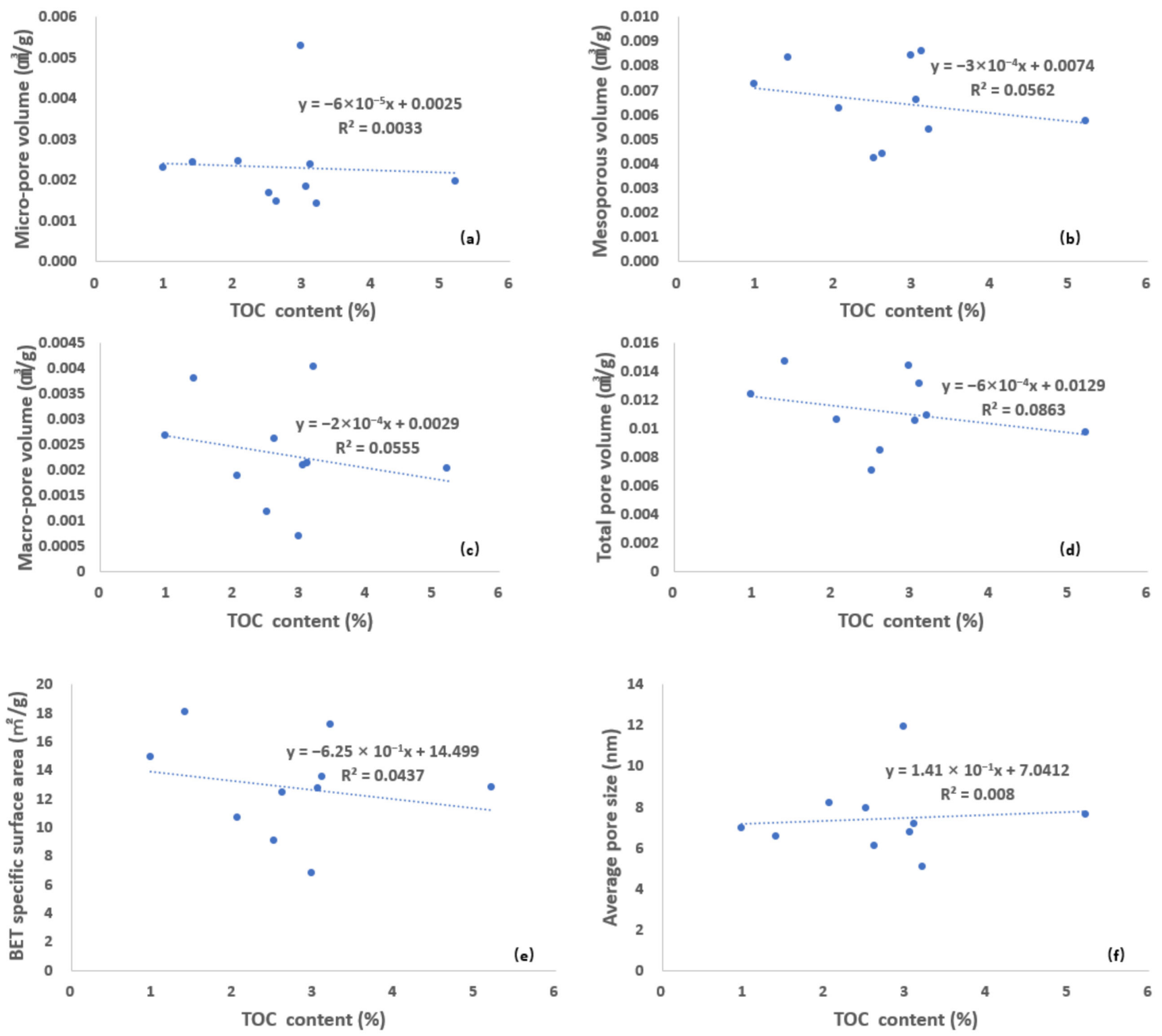

Figure 7. Relationship between microscopic pores and TOC content of lower Cambrian black shale from the Niutitang formation in Wenshuicun, Guizhou province; (a) the cross plot of micropore volume and the TOC content; (b) the cross plot of mesopore volume and the TOC content; (c) the cross plot of Macropore volume and the TOC content; (d) the cross plot of total pore volume and the TOC content; (e) the cross plot of BET specific surface area and the TOC content; (f) the cross plot of average pore size and the TOC content. 

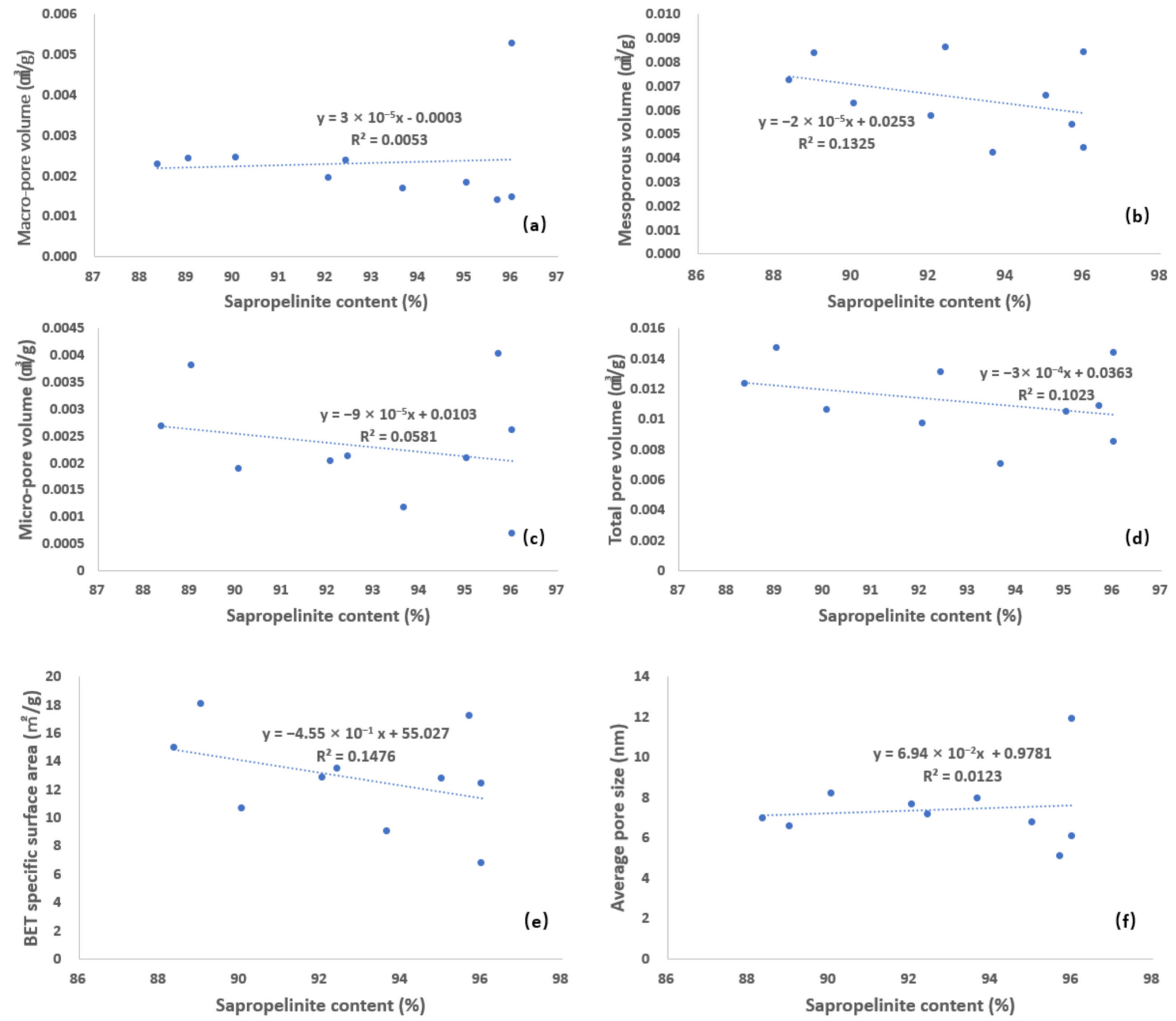

Figure 8. Relationship between micropores of lower Cambrian black shale and sapropelinite content from the Niutitang formation in Wenshuicun section, Guizhou province; (a) the cross plot of macropore volume and sapropelinite content; (b) the cross plot of mesoporous volume and sapropelinite content; (c) the cross plot of micropore volume and sapropelinite content; (d) the cross plot of Total pore volume and sapropelinite content; (e) the cross plot of BET specific surface area and sapropelinite content; (f) the cross plot of average pore size and sapropelinite content.

\subsubsection{The Influence of Thermal Maturity on Organic Pore Development}

As the degree of thermal evolution increases, the chemical composition and structure of kerogen will also change constantly, forming carbonaceous residues and eventually transforming into graphite [26]. This process is called carbonization. Zhang et al. (2017) [45] pointed out that the maturity threshold for the carbonization of organic matter was $3.2 \%$. At the same percentage, organic pores collapsed and decreased under compaction, reducing shale porosity. After measurement, the shale bitumen reflectance of the Niutitang formation was about $3.9 \%$, and the reduced vitrinite reflectance was also above $2.8 \%$, which indicates that it belongs to the over-mature stage. Combined with the above observation results, no organic matter pores were found in the shale in this region, indicating that, due to the over maturity of the shale, carbonization has occurred, resulting in the change of shale microstructure and the deformation and collapse of organic pores. Meanwhile, under the action of confining pressure and compaction, organic pores were further destroyed and 
eventually died out. This is consistent with the research results of some foreign scholars [46].
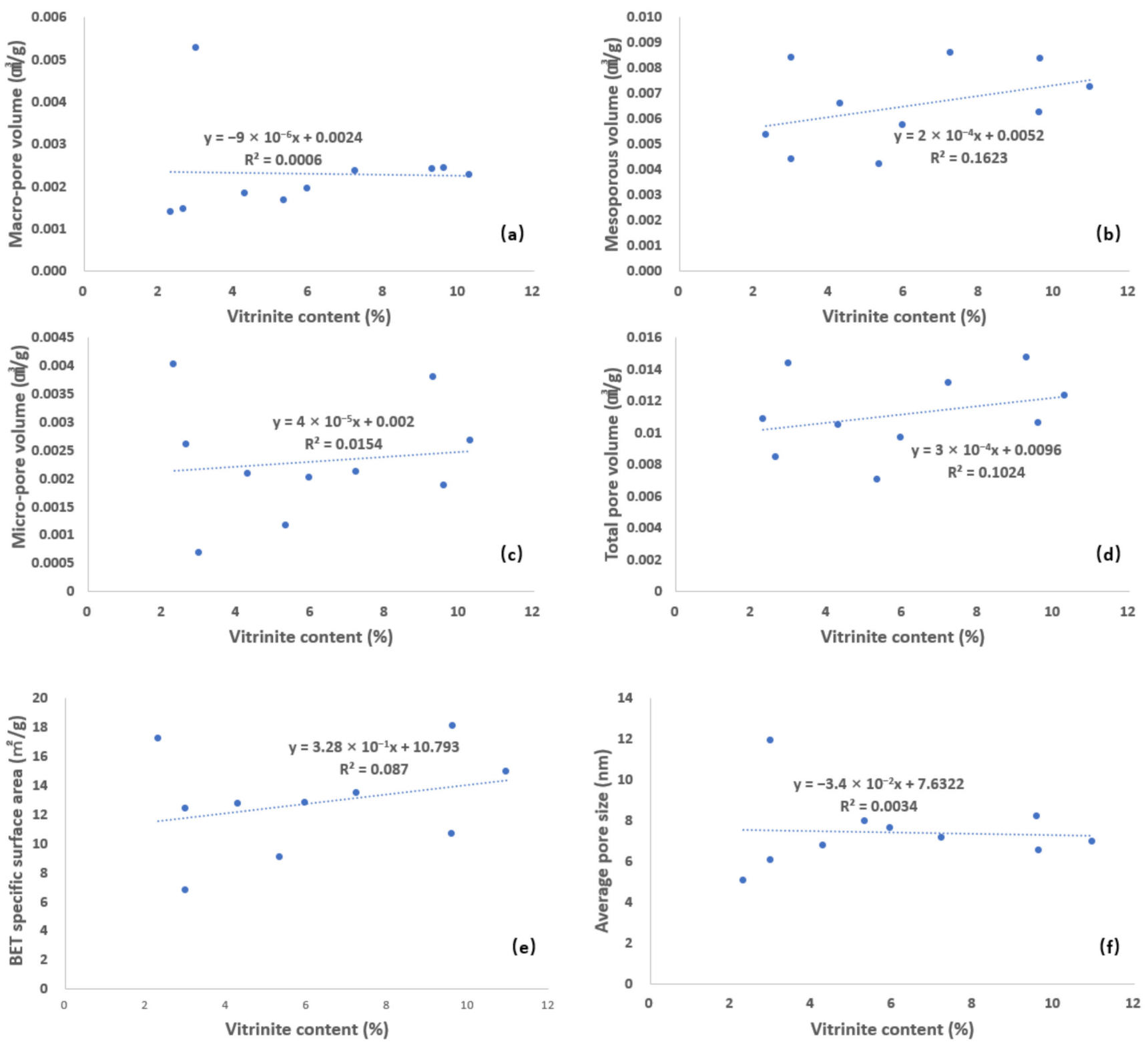

Figure 9. Relationship between microscopic pores and vitrinite content of lower Cambrian black shale from the Niutitang formation in Wenshuicun section, Guizhou province; (a) the cross plot of macropore volume and vitrinite content; (b) the cross plot of mesoporous volume and vitrinite content; (c) the cross plot of micropore volume and vitrinite content; (d) the cross plot of total pore volume and vitrinite content; (e) the cross plot of BET specific surface area and vitrinite content; (f) the cross plot of average pore size and vitrinite content.

\subsection{The Influence of Inorganic Minerals on Shale Pore Development}

\subsubsection{Content and Composition of Clay Minerals}

The transformation of different components in clay minerals may produce certain microcracks or cracks. For example, during the transformation of calcium smectite to illite, the unit structural height $\left(\mathrm{d}_{\mathrm{o}}\right)$ of smectite decreases by $33.3 \%$, leading to the collapse of the smectite structure and the formation of fractures in the shale. In addition, the content of montmorillonite and mixed layer minerals is proportional to the degree of fracture development [47]. Utpalendu kuila et al. (2013) [48] found that montmorillonite has micropores and fine mesopores with a characteristic pore size of $3 \mathrm{~nm}$ that is missing in kaolinite. Clay 
minerals mainly develop tabular pores with large pore sizes, from micro-pores $(<2 \mathrm{~nm})$ to macro-pores $(>50 \mathrm{~nm}$ ) [49]. Lu et al. (2020) [50] found that the same water-rock interaction conditions have different effects on different components of clay minerals. After water absorption occurs in illite, the crystal cell spacing changes little, as illite has poor water absorption and expansion, while in montmorillonite, the crystal cell spacing changes greatly after water absorption; furthermore, the water absorption of montmorillonite can easily to form hydration micro-cracks in the immorillonite mixed layer. Jin et al. (2018) [51], combined with previous studies, divided the diagenesis of montmorillonite and related clay minerals into three main stages, including: the early diagenetic stage, e.g. the development zone of the illite-montmorillonite mixed layer; the middle diagenetic stage (including early middle diagenesis and late middle diagenesis), e.g. the zone of kaolinite with an abnormally high content; and the late diagenetic stage, e.g. the zone for the development of illite and chlorite. According to the classification basis and the previous clay mineral analysis results, montmorillonite and related clay minerals in this region are in the late diagenetic stage.

Through the scatter plot, the correlation between microscopic pores (such as micropores, mesophores, macropores, total pore volumes, BET-specific surface area and average pore size) and different minerals was established. It was found that the clay mineral content of the lower Cambrian Niutitang formation black shale had an obviously positive correlation with macropore volume and average pore size; correlation coefficients are 0.5286 and 0.735 (Figure 10a,f), respectively. There was a good negative correlation between micropore volume and BET-specific surface area $\left(R^{2}=0.483\right.$ and $R^{2}=0.5084$ respectively) (Figure 10c,e). The correlation between mesoporous volume and total pore volume was weak or non-existent (Figure 10b,d). The above evidence indicates that the content of clay minerals was the main controlling factor for the development of microscopic pores in shale in this region. With the increase of clay mineral content, the micro-pore volume became smaller and smaller, while the larger pore volume above $25 \mathrm{~nm}$ became larger and larger.

\subsubsection{The Influence of Feldspar Content on Pore System}

There was a good negative correlation between feldspar content and macropore volume, and average pore size, with correlation coefficients being 0.3263 and 0.5926 , respectively (Figure 11a,e). However, there was a good positive correlation with micropore volume. The correlation coefficient was 0.3822 (Figure 11c). Meanwhile, it showed a good positive correlation with BET-specific surface area $\left(R^{2}=0.3787\right)$ (Figure 11f). But there was a weak negative correlation or no correlation with mesopore volume and total pore volume (Figure $11 \mathrm{~b}, \mathrm{~d}$ ). With the increase of feldspar content, the volume of large nanopores became smaller and smaller, while the volume of micropores below $5 \mathrm{~nm}$ increased. Therefore, feldspar content also had an effect on the development of microscopic pores in shale in this region. 

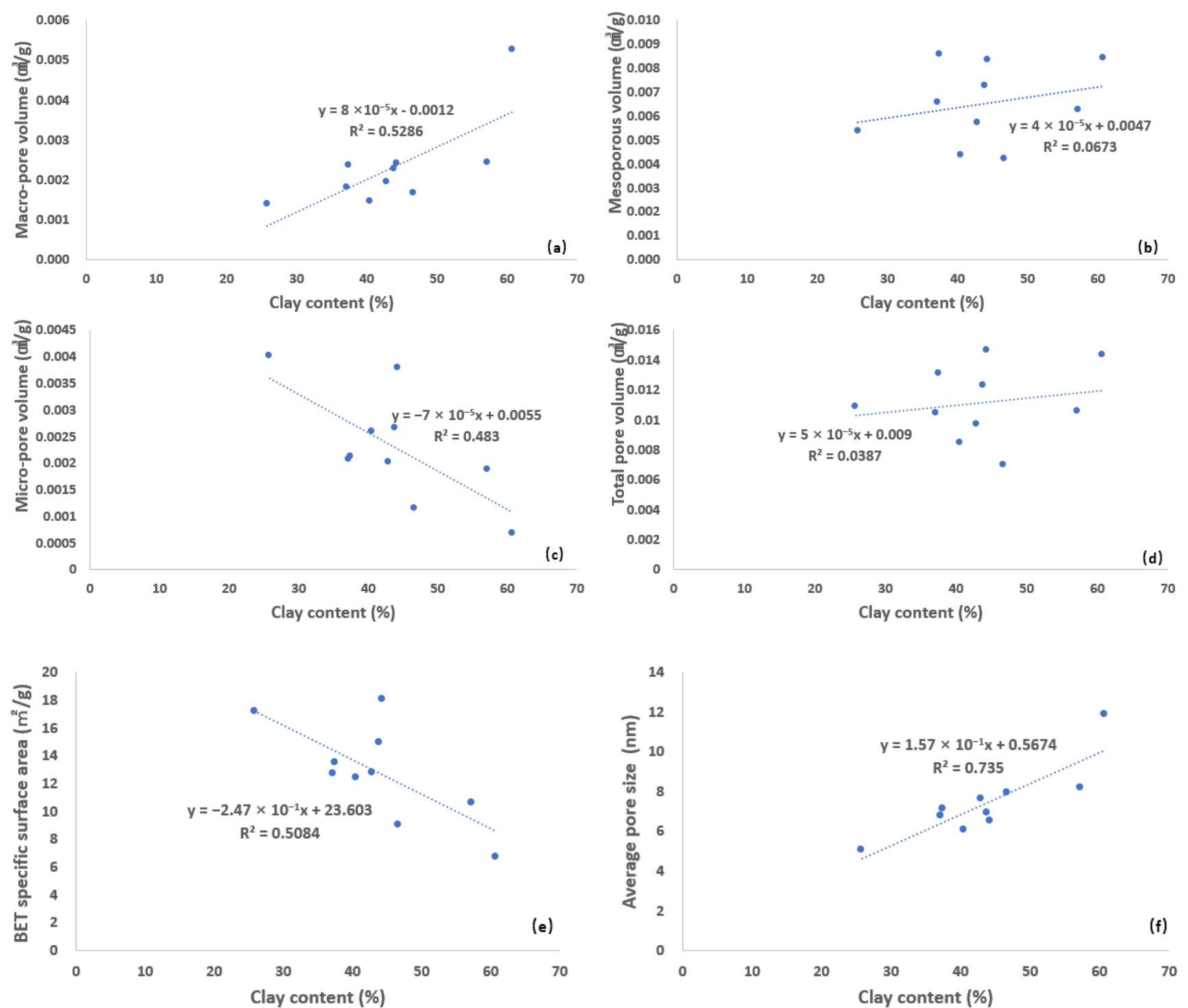

Figure 10. Relationship between microscopic pores and clay content of lower Cambrian Niutitang formation black shale in Wenshuicun section, Guizhou province; (a) the cross plot of macropore volume and clay content; (b) the cross plot of mesopore volume and clay content; (c) the cross plot of micropore volume and clay content; (d) the cross plot of total pore volume and clay content; (e) the cross plot of BET specific surface area and clay content; (f) the cross plot of average pore size and clay content. 

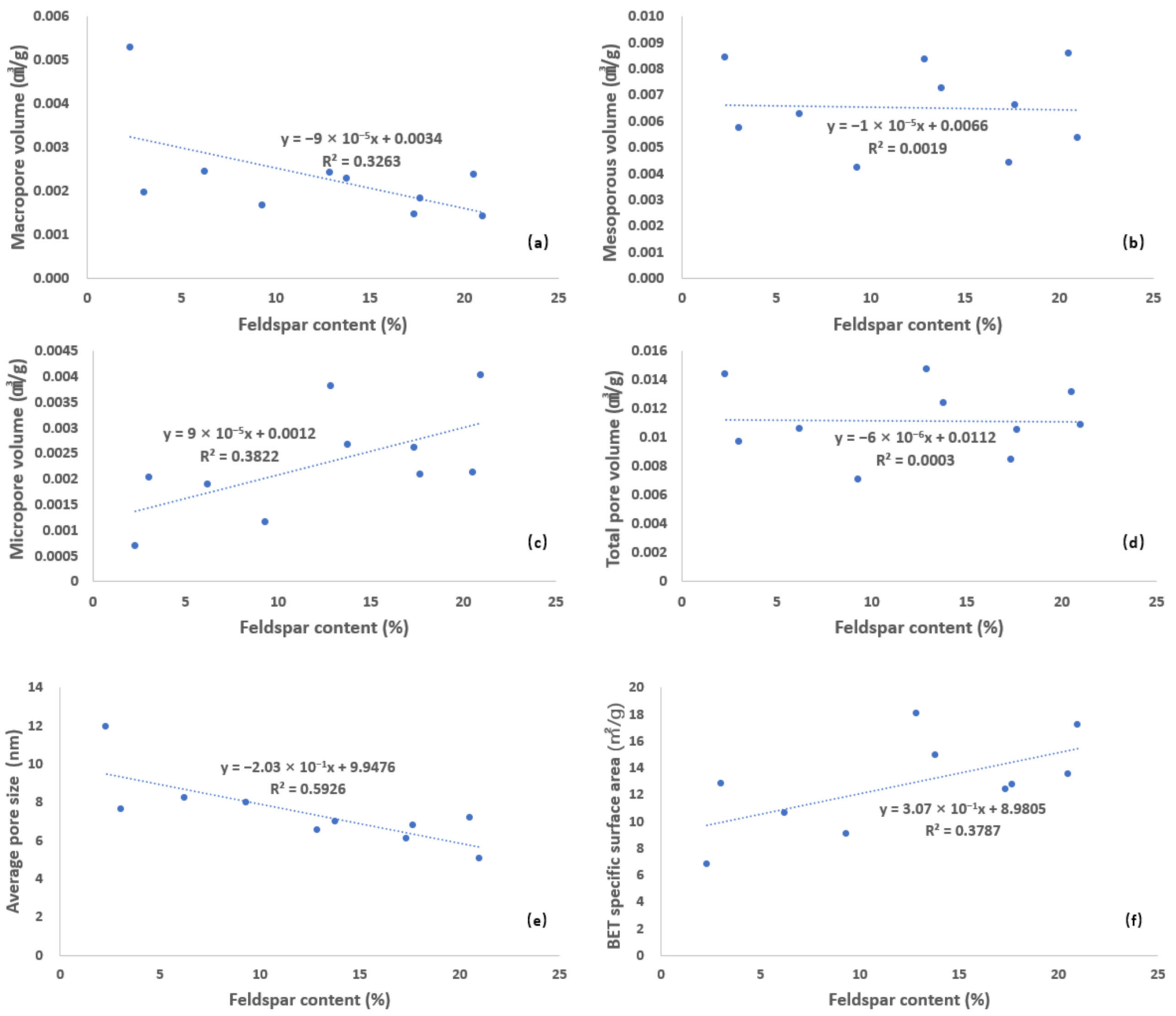

Figure 11. Relationship between microscopic pores and feldspar content of the lower Cambrian the Niutitang formation black shale in Wenshuicun section, Guizhou province; (a) the cross plot of macro-pore volume and feldspar content; (b) the cross plot of mesoporous volume and feldspar content; (c) the cross plot of micropore volume and feldspar content; (d) the cross plot of total pore volume and feldspar content; (e) the cross plot of BET specific surface area and feldspar content; (f) the cross plot of average pore size and feldspar content.

\section{Conclusions}

(1) The pore types of over-mature black shale of the Niutitang formation in Wenshuicun section, Guizhou province are mainly inorganic pores, generally including nanopores, and mesopores.

(2) The TOC content and organic matter type of shale in this region had little effect on the development of organic matter pores. In this region, organic matter pores were not developed in the over-mature Lower Cambrian shale.

(3) Inorganic mineral composition was the main controlling factor for the development of micropores in shale in this region. Clay mineral content had an obvious positive correlation with mesopore volume, macropore volume and average pore diameter, and a strong negative correlation with micropore volume.

(4) The over-mature Niutitang formation shale mainly developed inorganic pores, without the capacity of adsorbing gas. In the future, the Lower Cambrian shale gas development needs to exploit the areas with a low degree of thermal maturity and high TOC. 
Author Contributions: Conceptualization, D.L. and M.F.; methodology, D.L. and M.F.; validation, M.F.; formal analysis, D.L. and M.F.; investigation, D.L., M.F.,Y.H. and R.X.; resources, M.F.; data curation, D.L., M.F., Y.H. and R.X.; writing-original draft preparation, D.L., M.F., Y.H. and R.X.; writing-review and editing, D.L., M.F., and D.W.; visualization, D.L. and M.F.; supervision, M.F.; All authors have read and agreed to the published version of the manuscript.

Funding: This research was funded by Natural Science Foundation of Sichuan Province, China (Grant No. 16ZA0096).

Institutional Review Board Statement: Not applicable.

Informed Consent Statement: Not applicable.

Acknowledgments: We thank Xu Wang and Ma Ruolong from Chengdu University of Technology for their contribution to the sampling. We thank the State Key Laboratory of Oil and Gas Reservoir Geology and Exploitation in China for the measurement. This research was funded by Natural Science Foundation of Sichuan Province, China (Grant No. 16ZA0096).

Conflicts of Interest: The authors declare no conflict of interest.

\section{References}

1. Zhao, W.Z.; Jia, A.L.; Wei, Y.S.; Wang, J.L.; Zhu, H.Q. Progress in shale gas and exploration in China and prospects for future development. Pet. Explor. China 2020, 25, 31-44.

2. Zhou, C.N.; Zhao, Q.; Cong, L.Z.; Wang, H.Y.; Shi, Z.S.; Wu, J.; Pang, S.Y. Development potential and prospect of shale gas in China. Nat. Gas Ind. 2021, 41, 1-14.

3. Nie, H.K.; He, Z.L.; Liu, G.X.; Zhang, G.R.; Lu, Z.Y.; Li, D.H.; Sun, C.X. Status and direction of shale gas exploration and development in China. J. China Univ. Min. Technol. 2020, 49, 13-35.

4. Ma, Y.S.; Cai, X.Y.; Zhao, P.R. China's shale gas exploration and development: Understanding and practice. Pet. Explor. Dev. 2018, 45, 561-574. [CrossRef]

5. Zhou, C.N.; Dong, D.Z.; Wang, Y.M.; Li, X.J.; Huang, J.L.; Wang, S.F.; Guan, Q.Z.; Zhang, C.C.; Wang, H.Y.; Liu, H.L. Shale gas in China: Characteristics, Challenges and prospects (I). Pet. Explor. Dev. 2015, 42, 689-701.

6. Zhou, C.N.; Dong, D.Z.; Wang, Y.M.; Li, X.J.; Huang, J.L.; Wang, S.F.; Guan, Q.Z.; Zhang, C.C.; Wang, H.Y.; Liu, H.L. Shale gas in China: Characteristics, Challenges and prospects (II). Pet. Explor. Dev. 2016, 43, 166-178.

7. Dong, T.; He, Q.; He, S.; Zhai, G.; Zhang, Y.R.; Wei, S.L.; Wei, C.; Hou, Y.G.; Guo, X.W. Quartz types, origins and organic matter-hosted pore systems in the lower cambrian Niutitang Formation, middle yangtze platform, China. Mar. Pet. Geol. 2021, 123, 104739. [CrossRef]

8. Li, Y.; Qiao, D.; Jiang, W.; Zhang, C. Gas content of gas-bearing shale and its geological evaluation summary. Geol. Bull. China 2011, 30, 308-317.

9. Yang, C. Pore Development Characteristics and Main Controlling Factors of Shale Organic Matter; China University of Geosciences: Beijing, China, 2017.

10. Sun, W.J.B.; Zuo, Y.J.; Wu, Z.H.; Liu, H.; Zheng, L.J.; Wang, H.; Shuai, Y.; Lou, Y.L.; Xi, S.J.; Li, T.T. Pore characteristics and evolution mechanism of shale in a complex tectonic area: Case study of the Lower Cambrian Niutitang Formation in Northern Guizhou, Southwest China. J. Pet. Sci. Eng. 2020, 193, 107373. [CrossRef]

11. Ding, J.H.; Zhang, J.C.; Yang, C.; Huo, Z.P.; Lang, Y. Formation Evolution and Influencing Factors of Organic Pores in Shale. J. Southwest Pet. Univ. (Sci. Technol. Ed.) 2019, 41,33-44.

12. Qin, M.Y.; Cao, Z.; Guo, J.H.; Huang, Y.R.; Sun, L.P.; Dong, L. Characteristics of Shale Reservoir and Sweet Spot Identification of the Lower Cambrian Niutitang Formation in Northwestern Hunan Province, China. Acta Geol. Sin. (Engl. Ed.) 2019, 93, 573-587. [CrossRef]

13. Liang, F.; Qiu, X.X.; Dai, Y.; Zhang, Q.; Lu, B.; Chen, P.; Ma, C.; Qi, L.; Hu, X. Characteristics and main controls of nano-pores in the Lower Silurian Longmaxi shale, Sichuan Basin. Pet. Geol. Exp. 2020, 42, 920-927.

14. Xiong, L. The characteristics of pore development of the Lower Cambrian organic-rich shale in Sichuan Basin and its periphery. Nat. Gas Geosci. 2019, 3, 1319-1331.

15. Cao, T.T.; Liu, G.X.; Cao, Q.G.; Deng, M. Influence of maceral composition on organic pore development in shale: A case study of transitional Longtan Formation shale in eastern Sichuan Basin. Oil Gas Geol. 2018, 39, 40-53.

16. Borjigin, T.; Lu, L.F.; Yu, L.J.; Zhang, W.T.; Pan, A.Y.; Shen, B.J.; Wang, Y.; Yang, Y.F.; Gao, Z.W. Formation, preservation and connectivity control of organic pores in shale. Petrol. Explor. Develop. 2021, 48, 798-812. [CrossRef]

17. Guang, H.; Qian, P.; Kun, J.; Chao, W.H.; Zhi, W.L. Development of organic pores in the Longmaxi Formation overmature shales: Combined effffects of thermal maturity and organic matter composition. Mar. Pet. Geol. 2020, 116, 104314.

18. Wen, L.; Hu, S.Y.; Tian, H.Q. Study on Cambrian source rocks in Yangtze area. Northwest Geol. 2001, 34, 67-74.

19. Li, B.; Hu, B.; Luo, Q. Tectonic sequence stratigraphy and sedimentary environment evolution of prototype basin in middle and upper Yangtze Region. Coal Sci. Technol. 2018, 46, 19-27. 
20. Yi, T.S.; Zhao, X. Characteristics and distribution patterns of the Lower Cambrian Niutitang Shale reservoirs in Guizhou, China. Nat. Gas Ind. 2014, 34, 8-14.

21. Liu, Z.B.; Gao, B.; Zhang, Y.Y.; Du, W.; Feng, D.J.; Nie, H.K. Types and distribution of the shale sedimentary facies of the Lower Cambrian in Upper Yangtze area, South China. Pet. Explor. Dev. 2017, 44, 21-31. [CrossRef]

22. Zeng, W.T.; Ding, W.L.; Zhang, J.C.; Li, Y.X.; Wang, R.Y.; Jiu, K. Analyses of the characteristics and main controlling factors for the micro/nanopores in Niutitang shale from China's southeastern Chongqing and northern Guizhou regions. Earth Sci. Front. 2019, 26, 220-235.

23. Qing, J.Z.; Tao, G.L.; Teng, G.R.; Bian, L.Z.; Xie, X.M.; Fu, X.D. Htdrocarbon-forming organisms in excellent marine source rocks in south China. Pet. Geol. Exp. 2010, 32, 220-235.

24. George, O.A.; Phillips, R.I.; Francis, A.-D.; Ayoade, F.A.; Sphiwe, E.M.; Joshua, N.E.; Vincent, O.O.; Ademola, O.J.; Akintunde, I.A.; Niyiola, O.A. Geochemical evaluation of the carbonaceous shale of the upper cretaceous Anambra Basin for potential gas generation, Nigeria. Arab. J. Geosci. 2021, 14, 456.

25. Quaid, K.J.; Eric, R.; Tom, B.; Raphael, W. Organic petrography and thermal maturity of the Permian Roseneath and Murteree shales in the Cooper Basin, Australia. Int. J. Coal Geol. 2016, 154-155, 240-256.

26. Wang, S.F.; Zhang, Z.Y.; Dong, D.Z.; Wang, Y.M.; Li, X.J.; Hu, J.W.; Huang, J.L.; Guan, Q.Z. Microscopic pore structure and reasons making reservoir property weaker of Lower Cambrian Qiongzhusi shale Basin, China. Nat. Gas Geoscience. 2016, 27, 1619-1628.

27. Yuliana, Z.; Sakhaee-Pour, A. Modeling adsorption-desorption hysteresis in shales: Acyclic pore model. Fuel 2016, 181, 557-565.

28. Alessa, S.; Sakhaee-Pour, A.; Sadooni, F.N.; AI-Kuwari, H.A. Comprehensive pore size characterization of Midra shale. J. Pet. Sci. Eng. 2021, 203, 108576. [CrossRef]

29. Medina-Rodriguez, B.X.; Alvarado, V.; Hossain, M. Use of Gas Adsorption and Inversion Methods for Shale Pore Structure Characterization. Energies 2021, 14, 2880. [CrossRef]

30. Hackley, P.C.; Araujo, C.V.; Borrego, A.G.; Bouzinos, A.; Cardott, B.J.; Cook, A.C.; Eble, C.; Flores, D.; Gentzis, T.; Gonçalves, P.A.; et al Standardization of measurements in dispersed organic matter:Results of an exercise to improve inter laboratory agreement. Mar. Pet. Geol. 2015, 59, 22-34. [CrossRef]

31. Wang, Y.; Qiu, N.S.; Ma, Z.L.; Ning, C.X.; Zheng, L.J.; Zhou, Y.Y.; Fang, G.J.; Ran, X.Q.; Rao, D. Evaluation of equivalent relationship between vitrinite reflectance and solid bitumen reflectance. J. China Univ. Min. Technol. 2020, $49,563-575$.

32. Zhou, Z.; Pan, C. Paleotemperature Determination and Its Application in Sedimentary Basin; Guandong Science \& Technology Press: Guangzhou, China, 1992; pp. 1-225.

33. Jacob, H. Disperse solid bitumens as an indicator for migration and maturity in prospecting for oil and gas. Erdol Kohgle 1985, 38,365 .

34. He, J.X.; Duan, Y.; Zhang, X.L.; Wu, B.X. Geologic characteristics and hydrocarbon resource implication of the black shale in Niutitang Formation of the Lower Cambrian, Guizhou Province. J. Xi'Shiyou Univ. Nat. Sci. Ed. 2011, 26, 37-44.

35. Long, P.Y.; Zhang, J.C.; Jiang, W.L.; Nie, H.K.; Tang, X.; Han, S.B.; Xing, Y.W. Analysis on pores forming features and its influence factors of reservoir well Yuye-1. J. Cent. South Univ. (Sci. Technol.) 2012, 43, 3954-3963.

36. Huang, P.; Jiang, Z.X.; Cheng, L.J.; Wang, P.F.; Tang, X.L.; Wang, Z. Pore structural characteristics and their controlling factors of Niutitang-formation Shale in northeast Sichuan Basin. Pet. Geol. Oilfield Dev. Daqing 2016, 35, 152-162.

37. Chen, X.L.; Guo, T.X.; Shi, D.S.; Hou, Q.D.; Wang, C. Pore structure characteristics and adsorption capacity of Niutitang Formation shale in southern Shaanxi. Lithol. Reserv. 2019, 31, 52-60.

38. Cai, S.Y.; Xiao, Q.L.; Zhu, W.P.; Wang, X.L.; Yuan, H.; Chen, J.; Chen, S.P. Characteristics and controlling factors of nano pores in shale reservoirs of Wufeng-Longmaxi formations in southern Sichuan Basin: Insights from Shuanghe outcrop in Changning area. Pet. Geol. Exp. 2020, 42, 920-927.

39. He, Q.; He, S.; Dong, T.; Qu, G.Y.; Wang, Y.; Wan, K. Pore structure characteristics and controls of Lower Cambrian Niutitang Formation, western Hubei Province. Pet. Geol. Exp. 2019, 41, 530-539.

40. Wang, R.Y.; Gong, D.J.; Leng, J.G.; Wang, X.H.; Cong, S.; Ding, W.L.; Fu, F.Q.; Yang, T.; Lai, F.Q. Development characteristics of the Lower Cambrian Niutitang shale reservoir in Northern Guizhou area: A case study in Cengong block. Earth Sci. Front. 2017, 24, 286-299.

41. Zhang, C.; Li, H.C.; Liu, D.Y.; Peng, P.A. A comparative study of the pore structure of Niutitang shales at different tectonic positions in the Upper Yangtze region. Geochimica 2019, 48, 171-183.

42. Cao, T.T.; Song, Z.G. Influence of shale organic matter characteristics on organic pore development and reservoir. Spec. Oil Gas Reserv. 2016, 23, 7-13.

43. Tian, H.; Zhang, S.C.; Liu, S.B.; Zhang, H. Determination of organic-rich shale pore features by mercury injection and gas adsorption methods. Acta Pet. Sin. 2012, 33, 419-427.

44. Jiang, Z.X.; Li, X.; Wang, X.M.; Wang, G.Z.; Chou, H.Y.; Zhu, D.Y.; Jiang, H.Y. Characteristic differences and controlling factors of pores in typical South China shale. Oil Geol. 2021, 42, 41-53.

45. Zhang, J.K.; He, S.; Yan, X.L.; Hou, Y.G.; Chen, X.J. Structural characteristics and thermal evolution of nanoporosity in shales. J. China Univ. Pet. Ed. Nat. Sci. 2017, 41, 11-24.

46. Curtis, M.E.; Cardott, B.J.; Sondergeld, C.H.; Rai, C.S. Development of organic porosity in the Woodford Shale with increasing thermal maturity. Int. J. Coal Geol. 2012, 103, 26-31. [CrossRef] 
47. Zhao, X.; He, D. Clay Minerals and Shale Gas. Xinjiang Pet. Geol. 2012, 33, 643-647.

48. Utpalendu, K.; Manika, P. Specific surface area and pore-size distribution in clays and shales. Geophys. Prospect. 2013, 61, 341-362.

49. Li, W.B.; Lu, S.F.; Li, J.Q.; Zhang, P.F.; Chen, C.; Wang, S.Y. The coupling relationship between material composition and pore microstructure of southern China marine shale. Nat. Gas Geosci. 2019, 30, 27-38.

50. Lu, Y.H.; Yang, D.R.; Jin, Y.; Liang, C. Micro-mechanism of water-rock interaction of clay minerals in a deep shale gas reservoir in the Longmaxi Formation. Geochimica 2020, 49, 76-83. [CrossRef]

51. Jin, P.P.; Ou, C.H.; Ma, Z.G.; Li, D.; Ren, Y.J.; Zhao, Y.F. Evolution of montmorillonite and its related minerals and their effects on shale gas development. Geophys. Prospect. Pet. 2018, 57, 344-355. 